\title{
Analysis of fatty acids in Ghee and olive oil and their probable causal effect in lipoid pneumonia
}

\author{
Zein Mirghani, ${ }^{1}$ Tayseer Zein, ${ }^{2}$ Samuel Annoble, ${ }^{3}$ John Winter, ${ }^{4}$ Randa Mostafa ${ }^{1}$ \\ ${ }^{1}$ College of Medicine, university of Sharjah, UAE \\ ${ }^{2}$ Al Quassimi hospital, Sharjah, UAE \\ ${ }^{3}$ Pediatric department, university of Accra, Ghana \\ ${ }^{4}$ Science department, Glamorgan University, U.K
}

\begin{abstract}
Abstrak
Tujuan: Untuk menganalisis dan mengidentifikasi asam lemak yang ditemukan dalam "Ghee" buatan sendiri dan dalam minyak zaitun dan membandingkan dengan asam lemak yang ditemukan dalam bilasan bronkus pada anak dengan pneumonia lipoid.

Metode: Asam lemak yang ditemukan dalam lemak "Ghee" dan minyak zaitun dianalisis dengan kromatografi gas. Derivat metil ester untuk analisis GC disiapkan langsung dari minyak zaitun atau dari Ghee menggunakan metanol-HCl anhidrat. Bronkoskopi dan lavage bronkoalevolar dilakukan pada delapan anak usia antara 2 dan 4 tahun, semua dengan riwayat menggunakan Ghee buatan sendiri atau minyak zaitun pada posisi terlentang.
\end{abstract}

Hasil: Analisis asam lemak dalam Ghee dan minyak zaitun menunjukkan pola kromatografi gas yang sama seperti pada lavage bronkoalevolar.

Kesimpulan: Ketiga asam lemakterdeteksi bertanggung jawab atas terjadinya pneumonia lipoid. Pneumonia lipoid harus menjadi salah satu diagnosis banding pada anak-anak yang mengalami gangguan pernapasan. (Med J Indones 2010; 19:252-7)

\begin{abstract}
Aim: To analyze and identify the fatty acids found in homemade ghee and in olive oil and compare those to fatty acids found in bronchoalevolar lavage of children with lipoid pneumonia.

Methods: The fatty acids found in homemade fat "Ghee" and olive oil were analyzed by gas chromatography. Methyl ester derivatives suitable for GC analysis were prepared directly from olive oil or from Ghee using anhydrous methanolic-HCl. Bronchoscopy and bronchoalevolar lavage was performed in eight children aged between 2 and 4 years, all with history of using homemade ghee and/or olive oil in the recumbent position.

Results: The analysis of fatty acids in Ghee and olive oil show similar gas chromatographic pattern as those of bronchoalevolar lavage.

Conclusion: The three fatty acids responsible for the deleterious effects of lipoid pneumonia were identified. Lipoid pneumonia should be one of the differentials diagnosis in children presenting with respiratory distress. (Med $\mathbf{J}$ Indones 2010; 19:252-7)
\end{abstract}

Key Words: Bronchoalevolar lavage, gas chromatography, Ghee, methyl esters, lipoid pneumonia

Mineral oil lipoid pneumonia was prevalent when mineral oil was used as a base for nasal drops and its regular use as aperients ${ }^{1-8}$ but has now become rare with the advent of normal saline as base of nasal drops. Lipoid pneumonia due to animal fat, homemade ghee and olive oil is still encountered in certain parts of the globe because of cultural and traditional practices involving the use of oils and fats for various reasons. ${ }^{9-11}$ In Saudi Arabia, forced feeding of infants with homemade ghee in the recumbent position is believed to be beneficial to their health; however this has resulted in lipoid pneumonia, through clinical, radiological and pathological patterns in the acute stages, and in later stages through manifestation of bronchiectasis. ${ }^{11-17}$ Olive oil induced lipoid pneumonia is also seen in southwestern of Saudi Arabia however comparatively milder than / to severe cases. ${ }^{18}$

Lipoid pneumonia as a result of mineral oil aspiration occurs to date in pediatric patients in developing parts of the world. It mimics other diseases because it has nonspecific clinical presentation. Signs of lipoid pneumoniarangefrombeingasymptomatic withradiologic findings to acute or chronic symptoms attributable to pneumonia, pulmonary fibrosis or cor pulmonale. In asymptomatic patient it is often an incidental finding while in others it causes acute respiratory distress. The presence of lipids in alveolar macrophages has been clinically associated with increased lung inflammation 
in animal models. The hypothesis is that the quantity of lipids in alveolar macrophages measured as lipidladen would correlate with lung inflammation in pediatric patients. Accumulation of lipids in the cytoplasm of alveolar macrophages is considered to be evidence of aspiration. Whatever the pathway by which the fat or oil reaches the lung parenchyma, it either is absorbed by alveolar macrophages or remains free within the alveoli. Because alveolar macrophages cannot metabolize the lipid; when they die, the lipid is absorbed again into the alveoli.

The clinical diagnosis of lipoid pneumonia is complex. One reason is the difficulty in ascertaining the history of fat or oil ingestion. In addition, the symptoms appear only at an advanced stage of the illness. It has been reported that almost $50 \%$ of patients with lipoid pneumonia are asymptomatic. In many cases the disease is discovered by chance, during routine chest radiographs. The clinical symptoms (chest pain, dyspnoea, cough and fever) vary according to the duration, and the amount and quality of lipid aspirated. It is interesting however to analyze the fatty acids in bronchoalevolar lavage of patients suspected with lipoid pneumonia and relate the results to the fatty acids present in the aspired fat or oil. This paper outlines the identification of the fatty acids of two samples of homemade ghee and commonly available commercial olive oil and discusses their probable effects on the lungs in children with lipoid pneumonia.

\section{METHODS}

The fatty acids found in homemade fat "Ghee" and olive oil were analyzed by gas chromatography. Before analysis the derivatives of the fatty acids were obtained as follows:

\section{Transesterification: one step conversion of triglycerides to methyl ester derivatives (FAME)}

Methyl ester derivatives suitable for GC analysis were prepared directly from olive oil or from Ghee using anhydrous methanolic-HCl according to Christie's method. ${ }^{19}$ A two $\mathrm{cm}^{3}$ portion of a chloroform extract (ca $130 \mathrm{mg}$ lipid) was transferred to a weighed Sovirel test tube $\left(30 \mathrm{~cm}^{3}\right.$ screw capped). After complete removal of the solvent and with the test tube placed in a warm water bath (ca $35^{\circ} \mathrm{C}$ ), purged with a nitrogen gas jet, $4 \mathrm{~cm}^{3}$ of the methanolic- $\mathrm{HCl}$ reagent and $2 \mathrm{~cm}^{3}$ of purified dry hexane were added. The dead volume was purged with nitrogen gas and the tube was immediately sealed and heated for 2 hours, at $60^{\circ} \mathrm{C}$. After cooling and carefully releasing the tube cap, $10 \mathrm{~cm}^{3}$ sodium chloride solution $(5 \% \mathrm{w} / \mathrm{v})$ was added, and the methyl esters were extracted with $3 \times 6 \mathrm{~cm}^{3}$ portions of purified pentane, washed with $6 \mathrm{~cm}^{3}$ sodium bicarbonate solution $(2 \% \mathrm{w} / \mathrm{v})$, and dried over anhydrous magnesium sulphate. At this stage 1 $\mathrm{cm}^{3}$ of a solution of butyl hydroxy quinine (BHQ, $0.15 \%$ $\mathrm{w} / \mathrm{v}$ in pentane) was added so as to give a concentration of $0.1 \% \mathrm{w} / \mathrm{v}$ of the antioxidant in the final pure ester. ${ }^{20}$ The solution was then evaporated in nitrogen, weighed and quickly taken up in dry carbon disulphide $\left(\mathrm{CS}_{2}\right)$ so as to give ca. $10 \mathrm{mg}$ ester per $\mathrm{cm}^{3} \mathrm{CS}_{2}$. The esters were finally stored at $-20^{\circ} \mathrm{C}$ until required.

\section{Gas chromatography of FAME}

Five microlitres of FAME (olive oil or ghee) were injected in a GC capillary column (GC-MS Hewlett Packard bench top gas chromatograph). The column dimension are $25 \mathrm{~m} \times 0.32 \mathrm{~mm}$ fused silica (WCOT), CP wax 52 CB (df-0.2 m). Carrier gas was helium and column pressure was $70 \mathrm{kPa}(0.7 \mathrm{Bar}, 10 \mathrm{psi})$. Oven temperature was $160{ }^{\circ} \mathrm{C}-200{ }^{\circ} \mathrm{C}$ at $1{ }^{\circ} \mathrm{C} / \mathrm{min}$. Flame ionization detector was used. The eluent solvent was pure hexane. The injector port temperature was $200{ }^{\circ} \mathrm{C}$. Identification of each resolved peak in the chromatograph was determined by comparing the mass spectrometer fragmentation pattern of each peak in an acute integrates mode with a database of 54,000 compounds using PC-dedicated software. The results for each peak identified $>0.3 \%$ are detailed. In odd cases where auto-identification is in anyway dubious, then confirmation was obtained by analyzing a series of suitable standard mixtures of fatty acid methyl esters (FAMES) under the same GC-MS operating conditions.

\section{Bronchoscopy and bronchoalevolar lavage}

Bronchoscopy and bronchoalevolar lavage was performed in eight children aged between 2 and 4 years, all with history of using homemade ghee and/or olive oil in the recumbent position. All children show symptoms and signs of respiratory distress, and were clinically diagnosed with lipoid pneumonia. The bronchoalevolar lavage procedures were performed according to standard clinical protocols. The location of bronchoalevolar lavage was at the discretion of the bronchoscopist, but was generally performed in the lung segment most affected by the disease, as evidenced by radiological changes or by visual appearance at the bronchoscopy. The bronchoscope was wedged into a bronchus; and two to three 5-mL aliquots of buffered normal saline were instilled and immediately aspirated through the bronchoscope. The total volume of instilled lavage fluid was 1-3 mL per Kg body weight. The lipids were extracted from the lavage by chloroform methanol 1:1 mixture by volume, and the 
fatty acid methyl esters (FAME) were obtained by the same procedure as for ghee and olive oil. Five microliters samples were injected into the GC-MS instrument under similar operating conditions outlined above.

\section{RESULTS}

Gas chromatography and mass spectrometry were used to analyze the fatty acids content of homemade ghee and olive oil. The fatty acids contained in the homemade animal fat "ghee" are lauric, myristoleic, myristic, pendadecanoic, palmitoleic, heptadecanoic palmitic-straight and branched chains, linoleic, oleic, and stearic (Figure 1). Figure 2 shows the fatty acids present in olive oil are palmitoleic, palmitic-straight and branched, stearic, oleic and linoleic. These results show that fatty acids common to both "ghee" and olive oil (palmitic, palmitoleic, linoleic, oleic and stearic) may contribute to lipoid pneumonia, while the 5 fatty acids that are present solely in ghee, (lauric, myristoleic, myristic, pentadecanoic and heptadecanoic) may not have significant contribution to the disease.

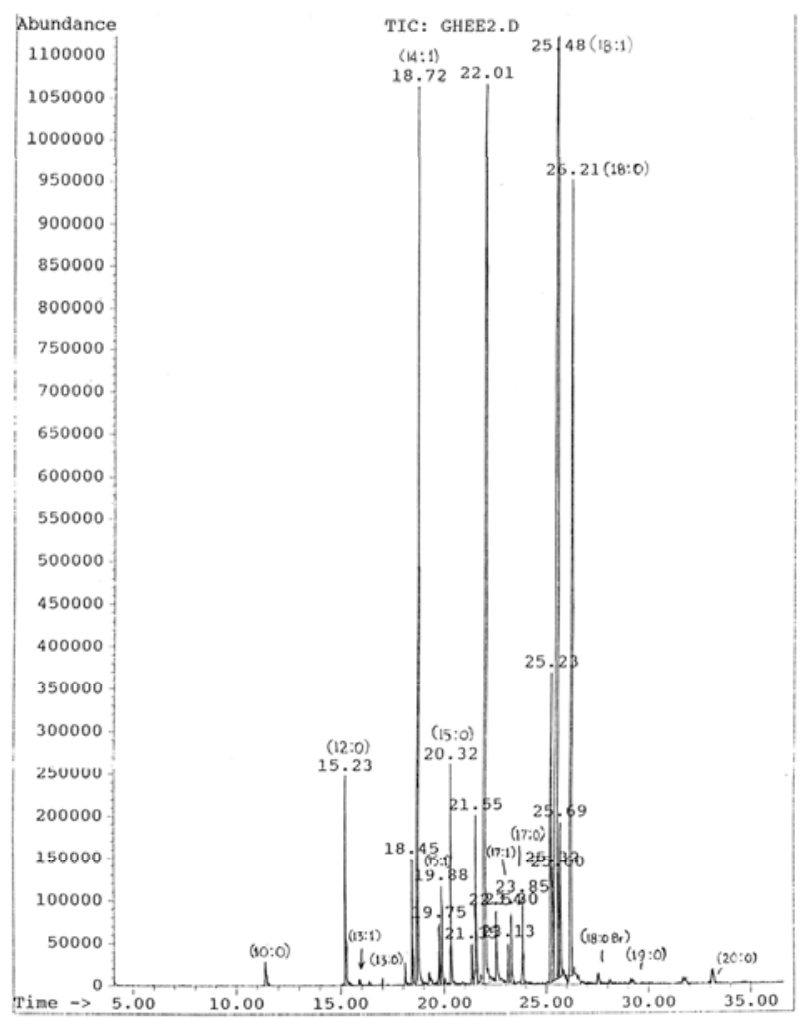

Figure 1. Gas chromatograph of fatty acids present in sample of homemade ghee

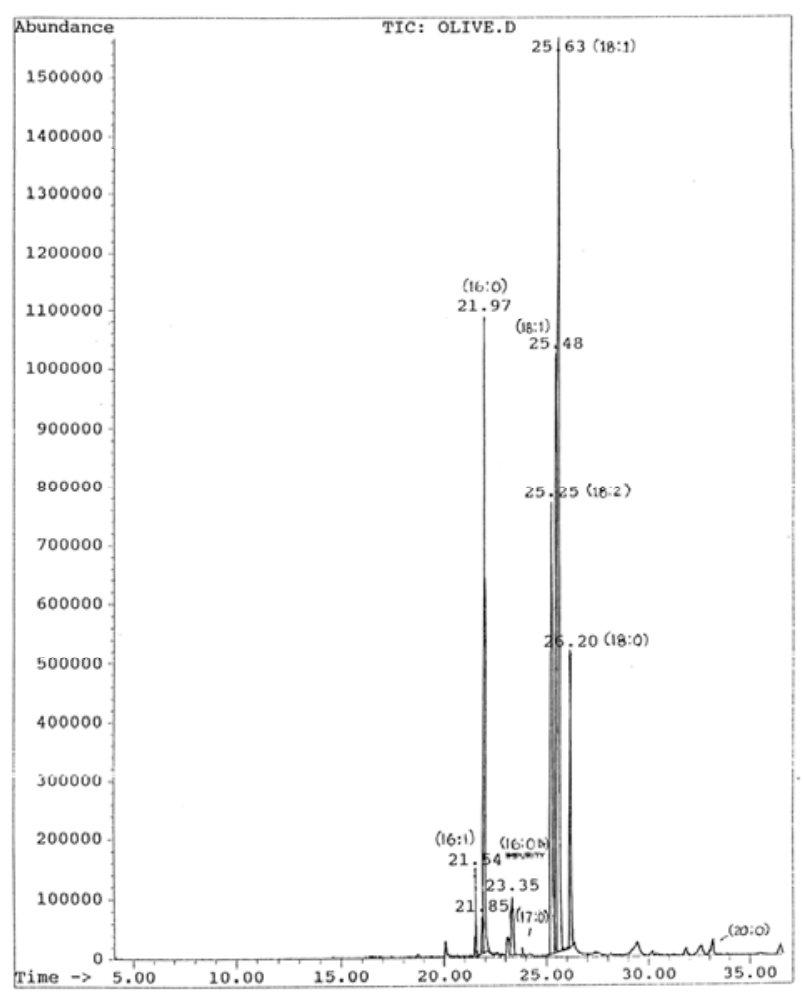

Figure 2. Gas chromatograph of fatty acids present in sample of olive oil

In order to determine the significant role of the identified fatty acids in the development of lipoid pneumonia, we sought to identify the types of fatty acids prevalent in the bronchoalevolar lavage of affected patients. We found that the fatty acids contents of the bronchoalevolar lavage of patients who used homemade ghee or olive oil show three main fatty acids which are common to both homemade ghee and olive oil. Comparison with GC-MS analysis of fatty acids of homemade ghee and olive oil are shown in figure 3a, b and c. GC-MS analysis of homemade ghee, olive oil and bronchoalevolar lavage, indicates that bronchoalevolar lavage contains only linoleic, oleic and staeric fatty acids, which are common to both homemade ghee and olive oil. Bronchoalevolar lavage on the other hand lacks the remaining fatty acids present in homemade ghee (lauric, myristoleic, myristic, pendadecanoic, palmitoleic, heptadecanoic and palmitic); and also lack two fatty acids present in olive oil (palmitoleic and palmitic). These results indicate that the fatty acids that may contribute to the development of lipoid pneumonia from homemade ghee and olive oil are one or more including linoleic, oleic and staeric fatty acids. 

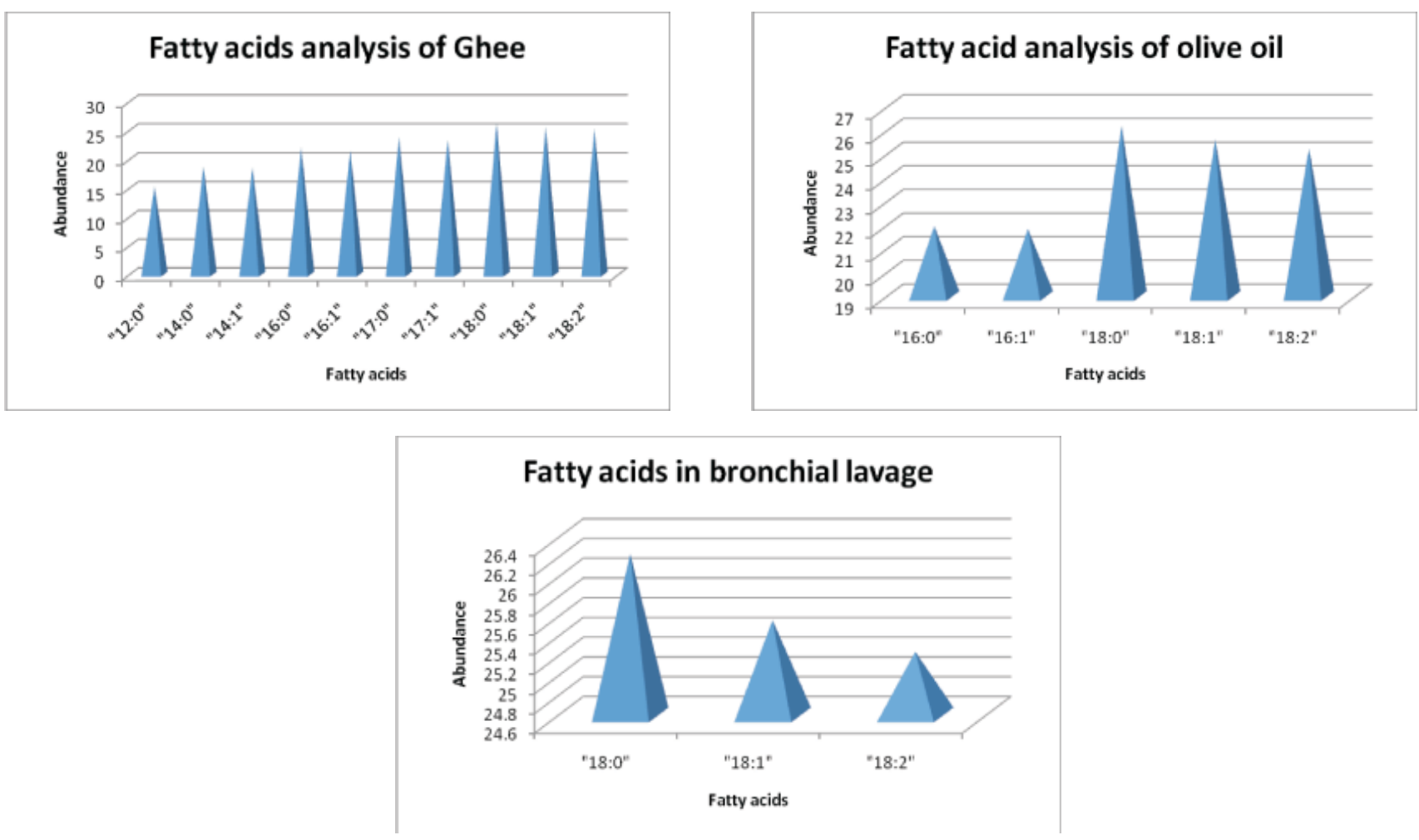

Figure. 3a, 3b, 3c. Abundance of fatty acids in ghee, olive oil and bronchoalevolar lavage

The identification of GC-MS fatty acids peaks in all samples were reconfirmed with mass spectrometric data base analysis of standard compound which are computer generated, and peak amplitudes were used in all analysis to show the abundance of a particular fatty acid.

\section{DISCUSSION}

We have identified the fatty acids from homemade ghee and olive oil that are potential candidates in causing lipoid pneumonia. Our results strongly implicate one or more of the fatty acids contained in homemade ghee and / or in olive oil in the development of this disease. The structure of these fatty acids identified is suggestive of their function. The long chain fatty acids of ghee are mainly non-volatile and may play a role in the severe lung pneumonic changes in lipoid pneumonia which is seen in children in developing countries. It further be postulated that some of the double bond introduced during the process of making the homemade ghee are not metabolized in the human lung, such as in oleic and linoleic acids. This may be due to the absence of enzymes in the lungs that are capable of metabolizing these fatty acids. Pinkerton found that oils which produce acute necrosis of the lung tissue are those oils and fats with the highest fatty acid content. ${ }^{2,3}$ The fatty acids of homemade ghee and olive oil are sufficiently irritating to initiate the humoral and cellular defense mechanisms. It is probable that if the amount of these fatty acids is overwhelming in quantity, and in the absence of the necessary enzyme to digest the oils and fat, then these may be the factors which may lead to the inadequacy of the defense mechanism and thereby lead to the severe damage of the lung tissue. We performed experiments to determine which of the ten different fatty acids in homemade ghee or those found in olive oil causes the deleterious effects on the lung.

It is found that lipids entering the lungs cause several drastic changes to the lung tissue. The lipids lower the $\mathrm{pH}$ of the cells lining of the alveolar-capillary interface, which may affect enzyme activity. In addition, this may result in several enzymes and inflammatory mediators to be released, such as lipoxygenase, tumor necrosis factor and interlukin-8. ${ }^{22-24}$ These factors would then present "outside" of their functional environment and potentially cause harmful effects on lung tissue. The temperature in the alveoli $\left(37^{\circ} \mathrm{C}\right)$ is well below the volatility temperature of any of the three long chain fatty acids present in the bronchoalevolar lavage; this would result in longer lifespan of these fatty acids, 
exposing lung tissues to additional damage. The physical state of ghee is semisolid and in this state it forms a thin layer covering the alveoli surface resulting is a decrease in the efficiency of gases exchange across the thin alveolar membranes, a function essential for lung health. Saturated and long chain fatty acids cause more damage to the lung because of their low volatility; form a film of lipids over the alveolar membrane; while the unsaturated and shorter fatty acids more volatile fatty acids are likely to enter the alveoli themselves The function of the lungs in lipid metabolism is not clear. Animal experiments have shown that lung microsomes's peroxidizes lipids at a 25 to 50 folds lower than each of liver, kidney, testes and brain microsomes. ${ }^{22-24}$ It is found that superoxide dismuatase (SOD) activity increased significantly in hamsters injected intratracheally with xanthine oxidase, and histopathology revealed peribronchiolar lipid peroxidation during lung ischemia, monitored by measurement of tissue thiobarbituric acid products conjugated dienes. Enhanced lipid peroxidation was observed after lung injury and in cancer tissue homogenates. Lung ischemia on the other hand results in small increase in lipogenesis but inhibits beta oxidation. The three fatty acids present in the bronchoalevolar lavage are typically eighteen carbons long chain, low volatility fatty acids, and if not metabolized by the lung are expected to cause more harm than other volatile fatty acids present in homemade ghee and olive oil. Bronchoalevolar lavage analysis has not revealed detectable amounts of any of the shorter more volatile fatty acids of homemade ghee and olive oil which indicates the presence of enzymatic activity which metabolizes these lower molecular weight fatty acids. It is evident that this study shows that lipoid pneumonia can be diagnosed by GC-MS analysis of bronchoalevolar lavage, and the harmful effects of lipoid pneumonia are caused by the less volatile long chain fatty acids of linoleic, oleic and stearic commonly present in homemade ghee and olive oil which are introduced in the recumbent position to children at very young age. This type of aspiration pneumonia cannot be ignored when investigating a child with pulmonary symptoms specifically in developing countries. Future studies are needed to find the effect of each of the three individual fatty acids on the lung parenchyma; on experimental animals, and to identify which fatty acid(s) is/are responsible for the deleterious effects of homemade ghee and olive oil.

In conclusions, there are three free fatty acids common to both homemade ghee and olive oil, namely, linoleic, oleic and stearic. These also happen to be found in highest amounts compared to other fatty acids found in the analysis of homemade ghee and olive oil. These three fatty acids are responsible for the delirious effects of lipoid pneumonia. Bronchoalevolar lavage fatty acids analysis can be used to diagnose lipoid pneumonia, and lipoid pneumonia should not be debarred from differentials in children from developing countries presenting with pulmonary symptoms or respiratory distress.

\section{REFERENCES}

1. Banjar H. Lipoid pneumonia. A Review. Bahrain Med. Bull. 2003; 25:36-9.

2. Furuya ME, Cordova M, Figueroa R, Vargas MH, Garcia RG, Juan RS. Cutoff values of lipid-laden alveolar macrophages for diagnosing aspiration in infants and children. Paediatr Pulmonol. 2007, 5:452-7.

3. Gil A. Polyunsaturated fatty acids and inflammatory disease. Biomed Pharmacother. 2002; 56(8):388-96.

4. Betancourt SL, Martinez JS, Rossi SE, Truong MT, Carrillo J, Erasmus JJ. Lipoid pneumonia: spectrum of clinical and radiologic manifestations. Am J Roentgenol. 2010; 194(1):103-9.

5. Siasi SM, Ferreirall AS, Daltrolli PA, Caetano RL, Moreira JS, Santos TQ. Evolution of exogenous lipoid pnuomonia in children: clinical aspects, radiological aspects and role of bronchoalevolar ravage. J Bra Pneumol 2009; 35(9):839-45.

6. Franquet T, Gimenez A, Roson N, Torrubia S, Sabate J, Perez G. Aspiration Disease, Pitfalls, and Dfferential Diagnosis. Radiographics 2000; 20:673-5.

7. Al-Kindi H, Abdoani R, EL-Iraqi M, Praseeda I. Lipoid Pemonia Following Aspiration of Ghee (animal fat) in an Omani Infant. Oman Med J. 2008; 23:123-5.

8. Ohwada A, Yoshioka Y, Shimanuki Y, Mitani K, Kumasaka T, Dambara T, Fukuchi Y. Exogenous lipoid pneumonia following ingestion of liquid paraffin. Intern Med. 2002; 41(6):483-6.

9. Hoffman LR, Elizabeth HY, Kanne JP, Effmann EL, Roland LG, Cornelius WV. Lipoid pneumonia due to Mexican folk remedies. Arch Pediatr Adolesc Med. 2005; 159:1043-8.

10. Adhisivam B, Mahadevan S. Olis that spoil the child. Ind J Paed. 2006; 73(6):88-9.

11. Kassarjan Y. An infant with respiratory distress. Clin Paediatr. 2001; 40:507-9.

12. Rossi SE, Franquet T, Volpacchino M, Gimenez A, Aguilar G. Tree-in Bud Pattern AT Thin-Section CT of the Lung: Radiologic-Pathologic Overview. RadioGraphics 2005; 25:789-801.

13. Zanetti G, Marchiori E, Gasparetto T, Escuissato D, Souza A. Lipoid pnenuomnia in children following mineral oil used in treatment of constipation: high resolution CT findings in 17 patients.Pediatr Radiol. 2007; 37:1135-9.

14. Khilnani GC, Hadda V. Lipoid pneumonia: an uncommon entity. Indian J Med Sci. 2009, 63:474-80.

15. Sias S, Pedro A, Daltro M, Marchiori E, Angela S, Ferreria M, Regina L, Caetano M, Cleonice S, Silva M, Muller M, Moreira J, Santos T. Clinic and radiological improvement 
of lipoid pneumonia with multiple bronchalveolar lavages. Pediatr Pulmol. 2009, 44(4):309-15.

16. Shira B, Haramati L, Vivan R. Radiological and clinical findings in acute and chronic exogenous lipoid pneumonia. J Thoracic Imaging 2003; 8(4):217-24.

17. Banjar HH. Areview of 151 cases of pediatric noncystic fibrosis bronchioectasis in tertiary care center. Ann Throc Med. 2007; 2:3-8.

18. Bobbak V, Timothy L. Complementary medicines and pulmonary toxicities: what a chest physician should know. Clin Pulmo Med. 2007; 14(6):338-45.

19. Christie W. W. Lipid analysis, London: Pergamon Press;1973. p88

20. Choong Y, Lin H. Gas chromatographic determination of synthetic antioxidants in edible fats and oils - a simple methylation method. J Food and Drug Analysis 2001; 1(9):20-6
21. Mirghani Z, Morad NA, Annobil SH, Adzaku FK, Kameswaran M. Effects of different types of oil aspiration in albino rats and its correlation with humans. Biomed Res. 2006; 17: 7-11.

22. Harizi H, Nobert G. 5-Lipoxygenase pathway: Dendritic cells, and adaptive immunity. J Biomed Biotechnol. 2004; 2:99-105.

23. Garantziotis S, Li Z, Potts EN, Lindsey JY, Stober VP, Polosukhin VV, Blackwell TS, Schwartz DA, Foster WM, Hollingsworth JW. TLR4 is necessary for hyaluronanmediated airway hyperresponsiveness after ozone inhalation. Am J Respir Crit Care Med. 2010; 181(7):666-75.

24. Mylonaki E, Voutas V, Antoniou D, Papakosta D, Kontakiotis T, Skordalaki A, Vafiadis E, Christaki P. Hydrocarbon pneumonitis following liquid paraffin aspiration during a fire-eating performance: a case report. J Med Case Reports 2008; 19(2): 214-5. 